\title{
SUSCEPTIBILITY OF PROVENANCES OF SPOTTED GUMS TO RAMULARIA SHOOT BLIGHT
}

\author{
N.M. SELF ${ }^{1}$, E.A.B. AITKEN ${ }^{2}$ and M.D. DALE ${ }^{3}$ \\ ${ }^{1}$ Ministry of Agriculture and Forestry, P.O. Box 2526, Wellington \\ ${ }^{2}$ Department of Botany, The University of Queensland, Qld 4072, Australia \\ ${ }^{3}$ P.O. Box 175, Mt. Nebo, Qld 4525, Australia \\ Corresponding author: selfm@maf.govt.nz.
}

\begin{abstract}
Shoot blight of spotted gums (Eucalyptus maculata Hook E. citriodora Hook and E. henryi S.T. Blake) caused by Ramularia pitereka Unger has recently emerged as the major disease problem of spotted gum plantations in Queensland and Northern New South Wales. A difference in disease susceptibility was demonstrated between provenances of spotted gums inoculated with Ramularia spores under field conditions. A number of other Eucalyptus species inoculated with Ramularia showed no susceptibility. The potential for breeding from resistant provenances and for creating resistant hybrids using crosses with resistant species, such as Eucalyptus torelliana F.Muell., is discussed.
\end{abstract}

Keywords: Ramularia pitereka, resistant provenances, Eucalyptus.

\section{INTRODUCTION}

Spotted gum is one of the most important commercial timbers in Queensland. It is an excellent structural timber with a density of over $1000 \mathrm{~kg} / \mathrm{m}^{3}$ (Cause et al. 1989) and a desirable timber for joinery and furniture. A need for commercial hardwood plantations has lead to the recent establishment of numerous plantations of spotted gum. However, shoot blight caused by Ramularia pitereka J. Walker and Bertus (Unger) (Walker \& Bertus 1971) (syn. Quambalaria pitereka Simpson 2000) has affected most, if not all of these new plantations. The incidence and severity of $R$. piterek $a$ in young plantations in Queensland (Qld) (Lee \& Nikles 1998) and Northern New South Wales (NSW) (Stone et al. 1998) makes it one of the most significant health problems facing hardwood forestry in Eastern Australia.

The shoot blight caused by $R$. pitereka causes distortion and twisting of young shoots, leaf spots and stem lesions. Repeated destruction of growing tips by $R$. pitereka leads to formation of a bushy crown with poor apical dominance. Damage is significant enough to force Queensland growers to choose alternative hardwood species as the disease has occurred wherever spotted gum has been grown. This study compares disease susceptibility of a number of provenances and species of spotted gums.

\section{MATERIALS AND METHODS}

A field trial was established to test the susceptibility of nine different provenances of eucalypts from the sub-genus Corymbia (Table 1). One provenance of E. resinifera (Symphomyrtus) was included as a non-susceptible control. The trial was located $12 \mathrm{~km}$ west of Brisbane (273' S, $\left.152^{\circ} 53^{\prime} \mathrm{E}\right)$. Seedling planting density was 10000 seedlings/ha comprising 25 individuals of each provenance in a complete randomised plot design. Fertiliser (N 12.5\%, P 2\%, K 5.5\%, S 17.5\%, Ca 4.4\% and Fe1\%) was applied (20 g/tree) four weeks after planting. Weed control was achieved by mowing and spraying glyphosate $(0.72 \% \mathrm{v} / \mathrm{v}$, Roundup), while control of phytophagous insects was achieved by spraying dimethoate $(0.075 \% \mathrm{v} / \mathrm{v}$, Rogor). Overhead irrigation was used during establishment. 
TABLE 1: Sources of seed used for host provenances testing for resistance to Ramularia pitereka.

\begin{tabular}{|c|c|c|c|c|c|c|}
\hline $\begin{array}{l}\text { Seedlot } \\
\text { Number }\end{array}$ & Species & Provenance & Latitude & Longitude & $\begin{array}{l}\text { Altitude } \\
(\mathrm{m})\end{array}$ & $\begin{array}{c}\text { Rainfall } \\
(\mathrm{mm})\end{array}$ \\
\hline 4399 & $\begin{array}{l}\text { Eucalyptus } \\
\text { maculata }\end{array}$ & $\begin{array}{l}\text { State Forest } 574 \\
\text { Leyburn, Qld }\end{array}$ & $28^{\circ} 03$ & $151^{\circ} 38$ & 500 & 650 \\
\hline 5554 & $\begin{array}{l}\text { Eucalyptus } \\
\text { henryi }\end{array}$ & $\begin{array}{l}\text { Myrtle creek State } \\
\text { Forests of NSW }\end{array}$ & $29^{\circ} 09$ & $152^{\circ} 59$ & 50 & 1350 \\
\hline 5583 & $\begin{array}{l}\text { Eucalyptus } \\
\text { maculata }\end{array}$ & $\begin{array}{l}\text { Richmond range } \\
\text { State Forests of NSW }\end{array}$ & $28^{\circ} 37$ & $152^{\circ} 45$ & 20 & 1090 \\
\hline 3506 & $\begin{array}{l}\text { Eucalyptus } \\
\text { citriodora }\end{array}$ & $\begin{array}{l}\text { Cheviot Hills } \\
\text { Holding, Qld }\end{array}$ & $19^{\circ} 38$ & $144^{\circ} 12$ & 920 & 673 \\
\hline 4384 & $\begin{array}{l}\text { Eucalyptus } \\
\text { torelliana }^{I}\end{array}$ & Brisbane, Qld & $27^{\circ} 28$ & $153^{\circ} 02$ & 38 & 1135 \\
\hline 4925 & $\begin{array}{l}\text { Eucalyptus } \\
\text { maculata }\end{array}$ & $\begin{array}{l}\text { State Forest } 50 \\
\text { Presho, Qld }\end{array}$ & $25^{\circ} 11$ & $149^{\circ} 10$ & 470 & 675 \\
\hline 4971 & $\begin{array}{l}\text { Eucalyptus } \\
\text { citriodora }\end{array}$ & Yeppoon, Qld & $23^{\circ} 10$ & $150^{\circ} 40$ & 50 & 1100 \\
\hline 5567 & $\begin{array}{l}\text { Eucalyptus } \\
\text { maculata }\end{array}$ & $\begin{array}{l}\text { State Forest } 393 \\
\text { Woondum, Qld }\end{array}$ & $26^{\circ} 15$ & $159^{\circ} 49$ & 400 & 1600 \\
\hline 10220 & $\begin{array}{l}\text { Eucalyptus } \\
\text { maculata }\end{array}$ & $\begin{array}{l}\text { State Forest } 627 \\
\text { Toolara, Qld }\end{array}$ & $26^{\circ} 07$ & $152^{\circ} 47$ & 130 & 1200 \\
\hline 3013 & $\begin{array}{l}\text { Eucalyptus } \\
\text { resinifera }\end{array}$ & $\begin{array}{l}\text { State Forest } 997 \\
\text { Noosa, Qld }\end{array}$ & $26^{\circ} 20$ & $152^{\circ} 57$ & 150 & 1800 \\
\hline
\end{tabular}

${ }^{I}$ The natural distribution of Eucalyptus torelliana is from $15.75^{\circ}$ to $19^{\circ} \mathrm{S}$, North Queensland.

Inoculum was obtained by washing spores from the surface of cultures (isolate FHS 50336) grown on MEA and from infected foliage. New shoots were sprayed with spore suspension 141 days after planting when trees were about $1 \mathrm{~m}$ tall. Each tree received approximately $15 \mathrm{ml}$ of spore suspension containing approximately $3 \times 10^{4}$ spores $/ \mathrm{ml}$, applied using a household plant sprayer after trees had been wetted using overhead irrigation. Disease assessments were made 40 and 89 days after inoculation.

In an additional experiment four other species were tested for susceptibility to Ramularia shoot blight (RSB) by placing potted seedlings under the drip zone of infected trees. The species were E. tessellaris, E. gummifera, E. intermedia and Angophora costata. Eucalyptus henri was included as a susceptible control.

Percentage of foliage affected by the disease was visually assessed using a method derived from Kershaw et al. (1988). In addition, counts were made of the number of infected shoots divided by the total number of shoots to give a proportion of shoots infected.

\section{Statistical analyses}

Differences in infection between host species/provenances were compared using T-tests on mean infection scores of five sub-blocks. Provenances were ranked and grouped according to mean infection by both proportion of new shoots infected and $\%$ of foliage infected. A comparison was made between the ability of each of these two assessment methods to discriminate differences in susceptibility between seedlots. Differences in foliar infection $(\%)$ and in the proportion of new shoots infected were validated using T-tests.

\section{RESULTS}

Uninoculated controls throughout the trial became infected soon after inoculation of the trial. The generation time of the fungus is very short with conidia observed on infected material less than a week after inoculation. No difference in infection was demonstrated 
between uninoculated control trees and inoculated controls. Uninoculated and inoculated trees were subsequently grouped together for further analyses. Infection was not observed on $E$. resinifera or E. torelliana. All of the eight other provenances were susceptible with demonstrable differences in both percentage of foliage infected and proportion of new shoots infected between provenances. Provenances were ranked according to the percentage of foliage infected and the proportion of new shoots infected (Table 2 ).

Difference between provenances within host species

Provenances of E. maculata from Leyburn (4399) and Presho (4925) sustained the highest levels of disease. Those from the Richmond range (5583) and Toolara (10220) were the most resistant. The Woondum provenance (5567), which appeared resistant and of good form in Queensland Forest Research Institute (QFRI) field trials (D.G. Nikles, pers. comm.), sustained a relatively high proportion of foliage infection, though it was not significantly less resistant than $5554,10220,3506$ or 5583 .

TABLE 2: Mean percentage of foliage infected and proportion of new shoots affected by Ramularia pitereka for ten host provenances.

\begin{tabular}{|c|c|c|c|c|c|c|}
\hline $\begin{array}{l}\text { Seedlot/ } \\
\text { provenance }\end{array}$ & $\begin{array}{l}\text { Percentage of } \\
\text { oliage infected }\end{array}$ & Rank $^{1}$ & $\begin{array}{l}\text { Std } \\
\text { Error }\end{array}$ & $\begin{array}{l}\text { Proportion of new } \\
\text { shoots infected }\end{array}$ & Rank & $\begin{array}{l}\text { Std } \\
\text { Error }\end{array}$ \\
\hline $\begin{array}{l}\text { E. torelliana } \\
4384 \text {, Brisbane }\end{array}$ & 0 & $\mathrm{a}$ & 0.0 & 0 & $\mathrm{a}$ & 0.000 \\
\hline $\begin{array}{l}\text { E. resinifera } \\
\text { 3013, Noosa }\end{array}$ & 0 & $\mathrm{a}$ & 0.0 & 0 & $\mathrm{a}$ & 0.000 \\
\hline $\begin{array}{l}\text { E. citriodora } \\
\text { 4971, Yeppoon }\end{array}$ & 13.1 & b & 2.0 & 0.523 & $\mathrm{~b}$ & 0.077 \\
\hline $\begin{array}{l}\text { E. maculata } \\
\text { 5583, Richmond R. }\end{array}$ & 13.8 & $\mathrm{bc}$ & 2.1 & 0.509 & $\mathrm{~b}$ & 0.059 \\
\hline $\begin{array}{l}\text { E. citriodora } \\
3506 \text {, Cheviot hills }\end{array}$ & 15.4 & bcd & 2.5 & 0.560 & bc & 0.111 \\
\hline $\begin{array}{l}\text { E. maculata } \\
\text { 10220, Toolara }\end{array}$ & 19.6 & bcde & 2.0 & 0.663 & $\mathrm{bc}$ & 0.092 \\
\hline $\begin{array}{l}\text { E. henryi } \\
\text { 5554, Myrtle creek }\end{array}$ & 19.8 & bcde & 3.6 & 0.710 & bc & 0.099 \\
\hline $\begin{array}{l}\text { E. maculata } \\
\text { 5567, Woondum }\end{array}$ & 21.1 & cde & 3.5 & 0.658 & b & 0.082 \\
\hline $\begin{array}{l}\text { E. maculata } \\
4399, \text { Leyburn }\end{array}$ & 25.0 & $\mathrm{e}$ & 4.0 & 0.714 & bc & 0.078 \\
\hline $\begin{array}{l}\text { E. maculata } \\
4925, \text { Presho }\end{array}$ & 27.6 & $\mathrm{e}$ & 3.3 & 0.822 & $\mathrm{c}$ & 0.080 \\
\hline
\end{tabular}

${ }^{1}$ Seedlots followed by the same letter are not significantly different $\mathrm{P}<0.05$.

Susceptibility of other related eucalypts to Ramularia shoot blight

Neither A. costata, E. intermedia, E. gummifera nor E. tessellaris became infected, while $9 / 10$ individuals of the known susceptible control $E$. henryi were infected after 8 weeks.

Comparison of methods used to assess infection

The foliage assessment method used in this study was faster than counting new shoots infected and total number of new shoots, and also gave less variable results, allowing greater resolution between provenances. The host seedlots could be divided into fivegroups, (a-e) based on T-tests of \% foliage infected, versus only three groups (a-c) based on proportion of new shoots infected (Table 2). 


\section{DISCUSSION}

Eucalyptus resinifera and E. torelliana remained uninfected throughout the trial. No records of natural infection of E. torelliana exist, either in forests or in nurseries. Two of the species which appeared resistant in this field trial have, in contrast, previously been reported as susceptible to R. pitereka in glasshouse trials: Angophora costata by Walker \& Bertus (1971) and E. torelliana by Dr M.H. Ivory, Forest Pathologist, QFRI (M.H. Ivory, pers. comm.). The results of this field trial are supported by the absence of any of records of naturally occurring infection in native stands or plantations of A. costata or E. torelliana. Though leaf spotting has been reported under artificial conditions, serious damage has never been reported on E. torelliana. This species may be a source of resistance for use in interspecific breeding with $E$. maculata and $E$. citriodora. It is possible that a proportion of hybrid progeny from this type of cross would inherit the desirable form of the E. maculata or E. citriodora parent and increased resistance from the E. torelliana parent (D.G. Nikles, pers. comm.).

Foliage assessment was both faster and provided better resolution between provenances than counting new shoots infected and total number of new shoots. It is also the most practical way to assess large numbers of trees aged more than 1-yearold, as the crown is out of reach but still within view in trees aged 1-3 years. While shoot counting is quantitative and arguably more reproducible, the objectivity of this method is still compromised as the assessor has to judge what constitutes a new shoot. On rapidly growing eucalypts carrying many shoots in all stages of development, this is difficult. Based on the results of this trial it is recommended that in future field trials investigating resistance to RSB, assessment of foliar infection in 5\% increments based on that used by Kershaw et al. (1988) should be employed. Advantages of this method are better discrimination between seedlots, larger trees can be assessed (subject to confirmation of the causal agent) and trees can be assessed for several seasons.

Differences in disease resistance within and between seedlots/provenances of spotted gums indicate breeding and selection of disease resistant stock are a promising avenue for minimising the impact of RSB. Difference in susceptibility between provenances is a major area that remains to be investigated further. Factors that have influenced the development of resistance in host trees from different locations remain undetermined. Mean annual rainfall of provenance location did not appear to have any demonstrable effect on susceptibility to $R$. pitereka (N.M. Self, unpubl. data). Available climatic information for many of these provenance locations did not provide further breakdown of climate data. Information such as summer rainfall, number of raindays and daily temperatures may provide sufficient resolution to enable differentiation between host provenances based on climate. Availability of information such as leaf wetness duration within a prescribed temperature range may better enable correlation of host susceptibility with provenance conditions.

This study found the provenance of E. maculata (5583) from Richmond Range NSW to have the highest resistance to RSB of the provenances of E. maculata tested. Mazanec (1999) recorded that a provenance from the Richmond Range was the top performer (for growth) amongst Corymbia variegata (F. Muell.) K. D. Hill and L. A. S. Johnson (this species was retained as E. maculata for this study). Provenances from the Richmond Range, NSW, should be included in further work on selection of resistant spotted gums. Woondum Provenance (5567), which has been observed as displaying higher resistance to RSB in QFRI provenance trials (D.G. Nikles, pers. comm.), performed relatively poorly, sustaining more percentage foliage infected than 4971 E. citriodora.

Significant variation in disease resistance exists within provenances of spotted gum. Selection of stock for breeding programmes should therefore also include outstanding families or individuals from unexceptional provenances. 


\section{REFERENCES}

Boland, D.J.; Brooker, M.I.H.; Chippendale, G.M.; Hall, N;.Hyland, B.P.M.; Johnston, R.D.; Kleinig. D.A.; Turner. J. D. 1984: Forest Trees of Australia fourth edition. CSIRO, Melbourne. $687 \mathrm{p}$.

Cause, M.L.; Rudder, E.J.; Kynaston, W.T. 1989: Queensland Timbers: Their Nomenclature, Density and Lyctid Susceptibility. Queensland Department of Forestry Technical Pamphlet No. 2. $126 \mathrm{p}$.

Kershaw, D.J.; Gadgil, P.D.; Ray, J.W.; van der Pas, J,B.; Blair, R.G. 1988: Assessment and control of Dothistroma needle blight (second, revised edition) FRI Bulletin No. 18. Ministry of Forestry, New Zealand.

Lee, D.J.; Nikles, D.G. 1998: Variation of incidence of Ramularia with Corymbia species, provenance and locality of planting and implications. QFRI Stock production and strategy group meeting note (Internal report). Queensland Forest Research Institute, Australia. $3 \mathrm{p}$.

Mazanec, R.A. 1999: Thirteen year results form a spotted gum provenance trial in the Wellington catchment of Western Australia. Australian Forestry 62(4): 315-319.

Simpson, J.A. 2000: Quambalaria, a new genus of eucalyptus pathogens. Australasian Mycologist 19 (2): 57-62.

Stone, C.; Simpson, J.A.; Eldridge, R.H. 1998: Insect and fungal damage to young eucalypt trial plantings in northern New South Wales. Australian Forestry 61 (1): 7-21.

Walker, J.; Bertus, A.L. 1971: Shoot blight of Eucalyptus spp. caused by an undescribed species of Ramularia. Proceedings Linnean Society NSW 96: 2108-17. 